\title{
A STUDY OF DETERIORATION PHENOMENA OF FOOT CASE CARTONNAGE FROM SAQQARA AREA, EGYPT
}

\author{
Hussein, A. ${ }^{1\left(^{*}\right)}$, Madkour, F. ${ }^{1}$, Afifi, $\mathrm{H}^{2}{ }^{2} \&$ Abd El Fatah, M. ${ }^{3}$ \\ ${ }^{1}$ Conservation dept., Faculty of Fine Arts, Minia Univ., Minia, Egypt \\ ${ }^{2}$ Conservation dept, Faculty of Archaeology, Cairo Univ., Giza, Egypt \\ ${ }^{3}$ Ministry of State for Antiquities Affairs of Egypt, Giza, Egypt. \\ E-mail: asmaa.moustafa@mu.edu.eg
}

\begin{abstract}
The aim of this paper is to study deterioration phenomena of foot case cartonnage from Saqqara area, Egypt. There are many damage problems such as: accumulation of dust, stains, cracks of ground layer and detachment of paint and gilded layers. An analyses and investigations of different samples were performed using a number of different analytical techniques. Light microscopy (LM), X-ray diffraction (XRD), scanning electron microscopy (SEM) equipped with an energy dispersive $X$-ray detector (EDS) and Fourier transform infrared spectroscopy coupled with attenuated total reflection (ATR-FTIR) were used. Analytical studies indicated that, cartonnage was composed of two layers; the coarse ground layer consisted of calcite and quartz as while the finer ground layer contained calcite only. Two layers of preparing double of linen textile were used as a separate layer between the previous ground layers. The pigments used for the decoration of cartonnage were identified as hematite, cinnabar and cuprorivaite. Gilded layer was identified as gold and silver. Microbiological investigation indicated the presence a fungal and bacterial infestation. The results obtained gave important knowledge about the deterioration processes of the foot case cartonnage.
\end{abstract}

Keywords: Cartonnage, Saqqara, Deterioration, Phenomena, Cracks, Microorganisms.

\section{Introduction}

Cartonnage is the term used for a type of mummy casing, made of gesso incorporating layers of papyrus or linen or both then painted [1]. It is a complex material that combines organic and inorganic materials [2]. These components are different in response to the impact of various damage factors, it is therefore more prone to damage and this causes its structure to weaken and over time loses its physical and mechanical properties. The cartonnage are also exposed to microbiological damage, which is considered one of the dangerous factors that cause damage. Microbiological species, such as fungi, bacteria and actionmycetes can cause aesthetic and structural damage [3]. Foot case cartonnage in this study is believed to date back to late period. It was discovered in one of the excavations in the Saqqara region, then thrown again after being discovered then extracted through an Egyptian mission in 1983. Saqqara area is one of the most famous places in Egypt situated about 10 miles $(16 \mathrm{~km}$.) from Giza, a suburb of Cairo, fig. (1). It was the principle necropolis, the ancient Egyptian capital city for much of the Pharaonic period which is dated back to the old 
Egyptian period ( $3^{\text {rd }}$ to $6^{\text {th }}$ dynasty). The total length of the necropolis is about 3.75 miles $(6 \mathrm{~km}$.), with a max. width of about a mile $(1.6 \mathrm{~km}$.) [4,5]. Over the centuries, remains have been discovered in the archaeological area of Saqqara and among these are some of the most beautiful and important of the ancient Egyptian civilization motives or elem- ents [6]. The main objective of this research is to evaluate deterioration phenomena of foot case cartonnage by using different analytical techniques such as light microscopy, XRD, SEM-EDS and ATR-FTIR to determine the appropriate methods of treatment and conservation methods.

Figure (1) Shows a map of the Saqqara area

\section{Deterioration Aspects of Foot Case Cartonnage}

The study of the aspects of the damage of foot case cartonnage is the first step of treatment and conservation of it, since understanding the nature of these aspects significantly determines the steps of restoration and conservation. Foot case cartonnage, fig. (2) is very fragile and distorted, either because of the burial environment it was in or because of the condition of the laboratory. The cartonnage suffers from many deterioration phenomena including accumulation of dust on the surface of foot case, also the presence of mud calcification covering a large part of the feet, fig. (2-a). This dust may be due to the impact of the burial environment. In addition to the presence of a large stain covering a large part of the right foot, fig. (2-b) which may be resulted in the resin materials used during the mummifycation of the mummy $[7,8]$. The outer and inner ground layer suffers from very fragile and weak aspects resulted in detachment of some parts from the support, fig. (2-c) that may be due to the hygroscopic nature of gesso layer, causing it to absorb water more readily than it loses it [9]. Thus may affect moisture on calcium carbonate, $\mathrm{CaCO}_{3}$ in the presence of carbon dioxide and it dissolves into calcium bicarbonate, $\mathrm{Ca}$ $\left(\mathrm{HCO}_{3}\right)_{2}$. Also the loss of the binding media from the preparation layer resulting to low of relative humidity (less than $50 \%$ relative humidity causes dryness of the organic medium) [10] or microrganisms feed on it as organic matter may be due to disintegration of ground layer $[11,12]$. Micro cracks and breaks in the painted surface because of fluctuations in temperature and relative humidity and the differential of expansion and contraction between the layers of cartonnage (support and gesso layer) [13,14]. Also the occurrence of flaking and exfoliation of paint layer, fig. (2-d) may be due to the loss of the binding layer of pigments [11]. It is observed in some of the paints on the cartonnage were damaged, such 
as Egyptian blue, fig. (2-e), which turned into a powder form probably because of it is made of coarse, relatively large and heterogeneous particles [15] or was attributed to the aging of organic binder [16]. The major problem with organic binders is their short lifetime due to their susceptibility to various degrading processes such as chemical and physicochemical processes that usually originate from oxygen and exposure to UV light [17]. Also observed the presence of residues of rodents and marks take shape (Z), fig. (2-f) spread to the paint layer were may indicate to microbiology attack or due to acid deposits from rats [10]. Some areas of the textile support suffer from separation of the two layers of fabric, fig. (2-g) perhaps because of high and low humidity leading to expansion and shrinkage of the tissue [18]. It also suffers from weak, tears and excisions may be because of poor handling and circular holes in tissue, fig. (2-h) which may indicate to an insect attack [19]. Flaking, microcracking and missing parts in the gilded layer of the toenails were destroyed which may be due to missing of binding media of gilding leaf or relative humidity fluctuation.
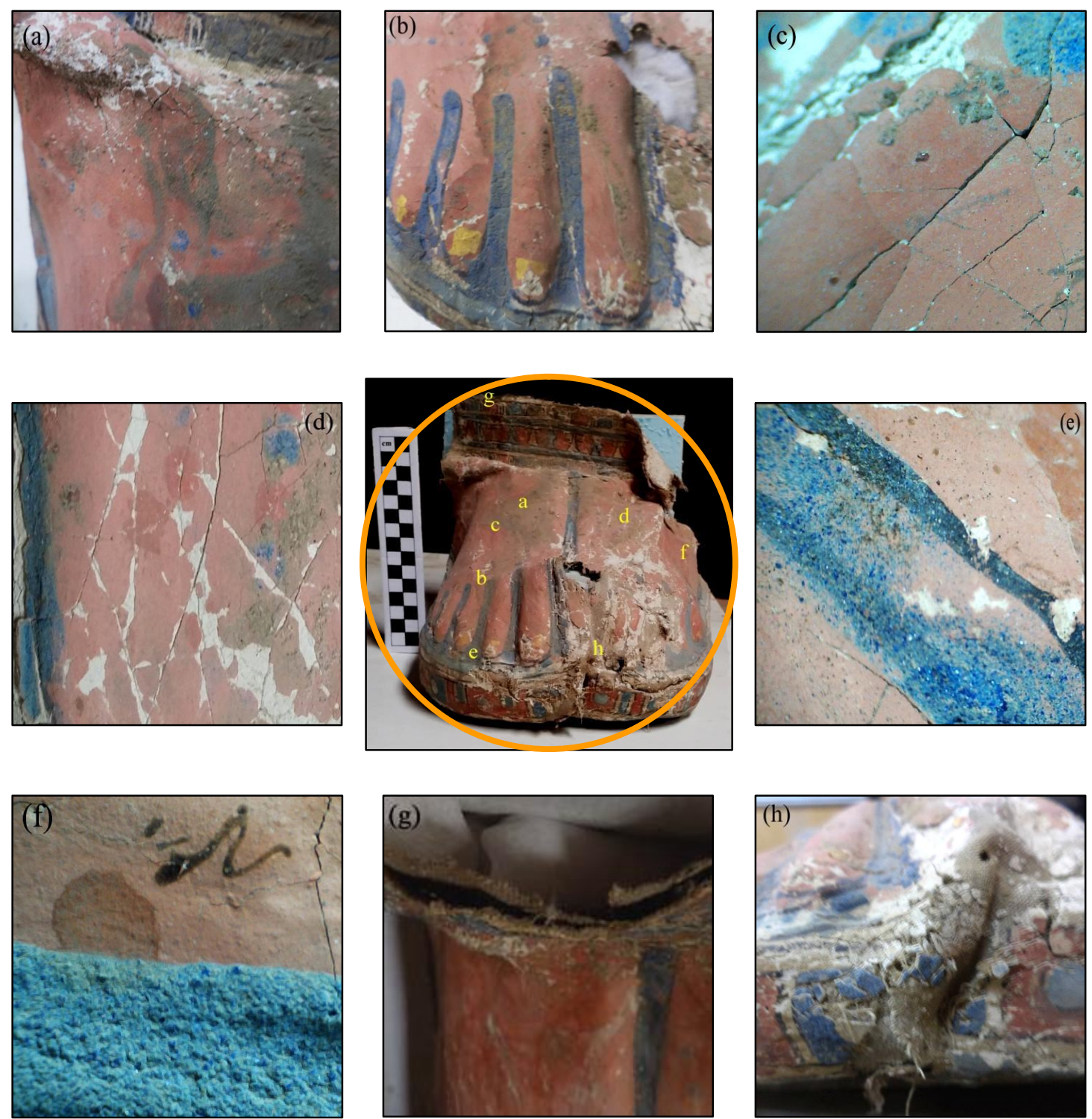

Figure (2) Shows deterioration phenomena of the foot case cartonnage a. accumulation of dust and mud calcification, $\underline{\mathbf{b}}$. stain covering the right foot, $\underline{\mathbf{c}}$. detachment and breakdown of outer ground layer, $\underline{\mathbf{d}}$. flaking and exfoliation of paint layer, $\underline{\mathbf{e}}$. blue pigment turned into a powder, $\underline{\mathbf{f}}$. marks take shape $(\mathrm{Z})$ spread to the paint layer may indicate an insect attack, g. separation of linen support, $\underline{\mathbf{h}}$. holes in textile 


\section{Materials and Methods}

\subsection{Sample collection}

The scientific analysis gives a complete picture of the type of damage to the cartonnage, such as the occurrence of morphological or composition changes. Samples were collected from different areas of foot case cartonnage carefully

\subsection{Analytical techniques}

\subsubsection{Light Microscopy}

The samples were observed by BTC BIM 313 T optical microscopy and recorded with a digital camera, as mobile 3.2.2. XRD analysis

XRD measurements were performed using XPERT-PRO-PANalytical diffractometer (Netherland), using $\mathrm{Cu}$ anticathode and $\mathrm{K} \alpha$ radiation with sec-

\subsubsection{SEM-EDS microanalysis}

Studies were carried out by using SEM Model FEI Quanta 250; the surface of samples is none coated. SEM images are taken by backscattered (BSE) and Secondary electrons (SE). It is equipped 3.2.4. FTIR -ATR spectroscopy analysis

Fourier transform infrared spectroscopy was carried using spectrometer VERTEX 70 (Bruker), equipped with an attenuated total reflection (ATR) sample stage. Spectra were recorded in absorb-

\subsubsection{Microbial examination}

Isolation and development of a number of microorganisms from different areas on the foot case cartonnage, to identify the most important microorganisms, which grow on it and lead to damage. Swab sampling technique was used, which swabs were taken from the different area of the foot case. These 3.2.5.1. Isolation of fungi

Petri dishes containing Czapek's medium consisting of $30 \mathrm{~g}$ sucrose, $2 \mathrm{~g}$ sodium nitrate, $1 \mathrm{~g}$. potassium dihydrogen phosphate, $0.5 \mathrm{~g}$. potassium chloride, $0.5 \mathrm{~g}$. magnesium sulfate, $0.01 \mathrm{~g}$. ferrous sulfate, $10 \mathrm{~g}$. agar and $1000 \mathrm{ml}$ tap water (pH 5.5-6) [21] were inoculated with the swabs at $28-30{ }^{\circ} \mathrm{C}$ for $5-7$ days, then according to the [20] from the ground layers, pigments, textile and gilded layers to determine their components, taking into consideration that samples are also representative of the manifestations of damage.

USB microscope was used to study damage to cartonnage.

ondary monochromator (45 KV, $40 \mathrm{MA}$ ), a flat sample holder and a $\mathrm{X}$ 'celerator detector.

with an energy-dispersive spectrometer (EDS) to identify the elemental composition of the materials. The accelerating voltage was $20-25 \mathrm{KV}$.

ance mode were obtained in the region of $600-4000 \mathrm{~cm}^{-1}$ at resolution $4 \mathrm{~cm}^{-1}$, 16 scans were averaged in order to obtain clear absorption spectra of each sample.

swabs are placed immediately after the insulation in sterile tubes for lack of contamination. As well as taken is isolated from the air in the room by putting Petri dishes with media suitable for the growth of microbes and left for ten minutes and then close dishes.

separation and purification of fungal colonies on dishes containing the potato dextrose agar (PDA) medium, which consists of $200 \mathrm{~g}$ potato extract, $20 \mathrm{~g}$. dextrose, 15g. agar and $1000 \mathrm{ml}$ distilled water ( $\mathrm{pH}$ 6.5) [22]. After 7 days of incubation at $28-30^{\circ} \mathrm{C}$ fungi are defined according to scientific references $[23,24]$. 


\subsubsection{Isolation of bacteria and actinomycetes}

Purification of bacterial and actinomycetes colonies on dishes containing the agar medium, which consists of $5 \mathrm{~g}$. peptone, $3 \mathrm{~g}$. beef extract, $5 \mathrm{~g}$. sodium chloride, 20g. agar and $1000 \mathrm{ml}$ distilled

\section{Results}

\subsection{Light microscopy}

The microscopic examination of the surface of dark red layer, shows white granules scattered on the surface, which may be due to the presence of salt crystals. Optical microscopic investigation of the brilliant red layer, fig. (3-a) shows circular and lightness grains. There were also some black spots in the brilliant red color. The gilded layer appears under the optical microscope irregularly, fig. (3-b), this may be due to the application of gold leaf on the pigments. It also appears to water ( $\mathrm{pH} 7.2)$ after 7 days of incubation at $30-37{ }^{\circ} \mathrm{C}$ bacteria and actionmycetes are defined according to reference procedures $[25,26]$.

have many micro-cracks and missing parts in some area of the gilded layer and the separation of parts and inflection of gilded leaf from the surface, fig. (3-c) which may be due to loss of organic binder used to adhesive gild foil. The optical ex-amination of textile support revealed that it is from linen where the nods appear in the fibers, the tissue composition is $1 / 1$, flax thread is approximately $250 \mu \mathrm{m}$ and thickness of fiber is about $13 \mu \mathrm{m}$.
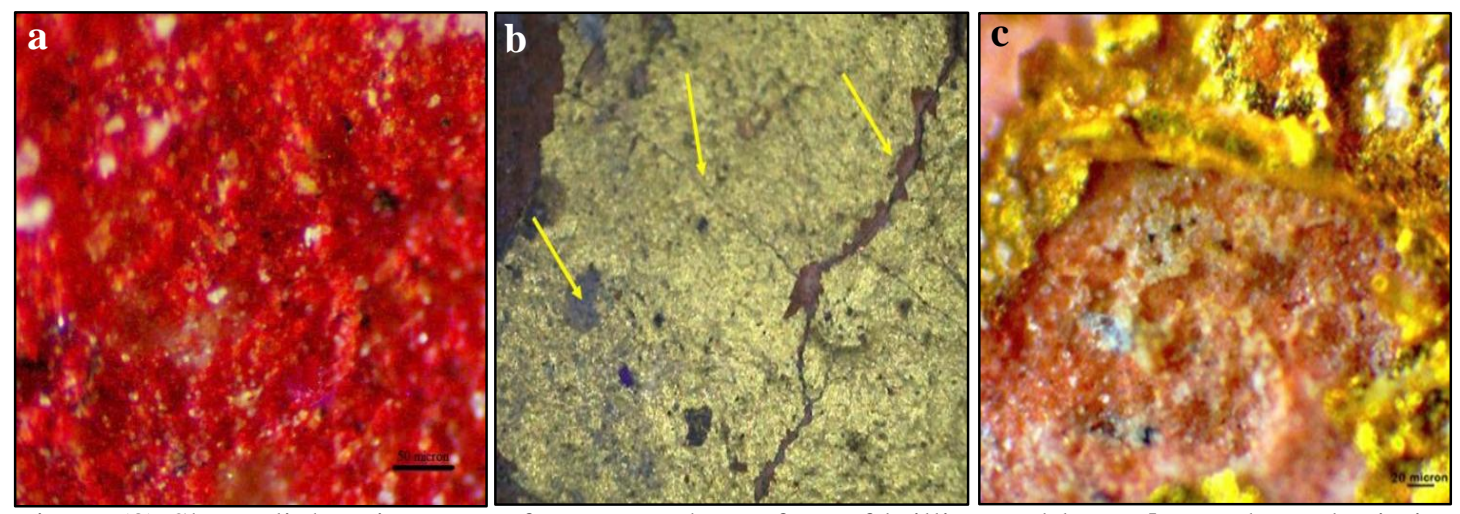

Figure (3) Shows light microscope features $\underline{\mathbf{a}}$. the surface of brilliant red layer, $\underline{\mathbf{b}}$. cracks and missing parts aspects in some area of the surface of gilding layer, $\underline{\mathbf{c}}$. separation parts and inflection of gilding leaf

\subsection{XRD results}

The results obtained form X-ray diffraction analysis showed that the outer ground layer consists of calcite $\left(\mathrm{CaCO}_{3}\right)$ only as a major component and calcite and quartz $\left(\mathrm{SiO}_{2}\right)$ revealed in the inner coarse ground layer. These results agreed with Afifi [27]. XRD results of dark red layer showed that sample consists of the calcite as main component, in addition to hematite $\left(\mathrm{Fe}_{2} \mathrm{O}_{3}\right)$ as a minor component. Also, XRD data of the brilliant red pigment sample shows that the sample consists of calcite as a major component and cinnabar $(\mathrm{HgS})$ as

a trace. Spectrum of XRD appeared that the dark blue paint sample, fig. (4) consists of calcite and quartz as a main components, in addition to, natron $\left(\mathrm{NaSO}_{4}\right.$. $\left.2 \mathrm{H}_{2} \mathrm{O}\right)$ and Egyptian blue $\left(\mathrm{CuCaSi}_{4} \mathrm{O}_{10}\right)$ as minor components. Natron may be result to contact of foot case with the mummified body, where it's used during the mummification process to dry the body $[28,29]$. XRD analysis results revealed that gilded layer consist of calcite as a major component mixed with traces of hematite $\left(\mathrm{Fe}_{2} \mathrm{O}_{3}\right)$, it may be due to the paint used below the gilded layer. 


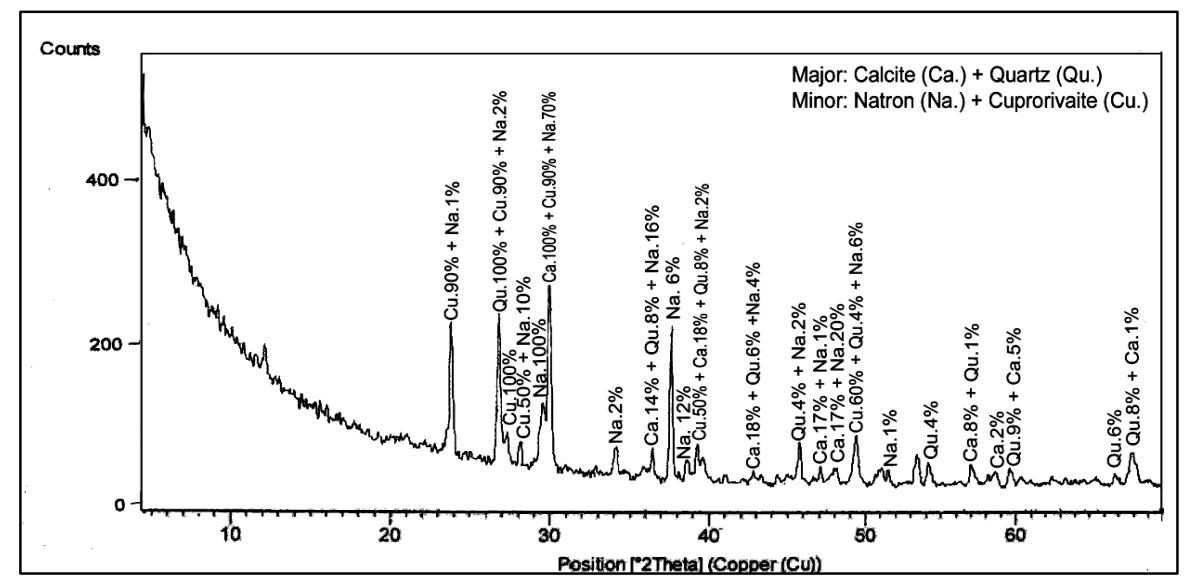

Figure (4) Shows of XRD pattern of dark blue paint sample

\subsection{SEM- EDX results}

The examination of a sample of the outer ground layer by SEM in backscattered (BS) mode, fig. (5-a) showed that the calcite granules were not correlated with each other and gaps between the crystals. SEM in secondary electrons (SE) mode of the inner ground layer, fig. (5b) shows presence of erosion and disintegration of crystals, as well as the presence of fungal hyphae overlapping between calcite granules. SEM-BS analysis of dark red layer shows micro-cracks and white crystals spread on the surface. The results of EDS analysis, fig. (5-c) showed the main elements are chloride (Cl) and sodium ( $\mathrm{Na}$ ), in addition to elements calcium $(\mathrm{Ca})$ and carbon $(\mathrm{C})$ from ground layer and iron (Fe) may be result to the use of hematite as a red pigment. SEM-BS of the brilliant red paint revealed luminous granules broken, while EDS, fig. (5-d) appears the elements mercury $(\mathrm{Hg})$ and sulfur (S) which may be indicating to cinnabar (HgS). SEM of the dark blue layer revealed that the surface of the sample was irregular due to the different sizes and shapes of the cuprorivaite crystals

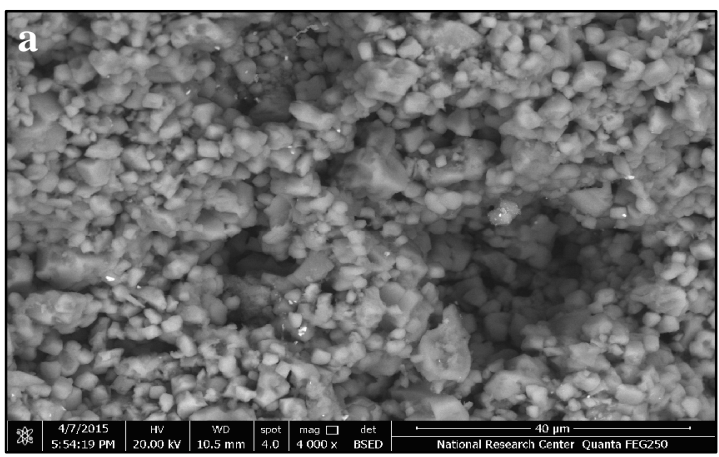

characteristic of the Egyptian blue color, also appeared halite salt crystal featured hexagonal form, attached to the dark blue crystals (cuprorivaite), fig. (5-e). EDX of the dark blue layer showed the presence peaks of calcium $(\mathrm{Ca})$, copper $(\mathrm{Cu})$ and silicon ( $\mathrm{Si}$ ) may be attributed to cuprorivaite, in addition to the elements of magnesium $(\mathrm{Mg})$ and aluminum $(\mathrm{Al})$, possibly from burial environment. Sodium (Na) and chloride $(\mathrm{Cl})$ probably refers to the presence of halite $(\mathrm{NaCl})$. The SEMSE of the gilded layer sample, fig. (5-f) revealed that there were three layers of gilding foil where the thickness of the single gold layer was about $2 \mu \mathrm{m}$. It is also noticed that the three layers are separated from each other. EDX of the same sample, fig. (5-g) showed the peaks of gold $\mathrm{Au}(97.7 \%)$, in addition to silver $\mathrm{Ag}(1 \%)$, copper $\mathrm{Cu}(0.9 \%)$ and zinc $\mathrm{Zn}(0.6 \%)$, its may be impurities in the gold. The examination of a sample of the textile, fig. (5-h) showed weakness and some flexions, lost of their strength and breakage in the fibers of the tissue also appears micro-cracks in one of the fibers.

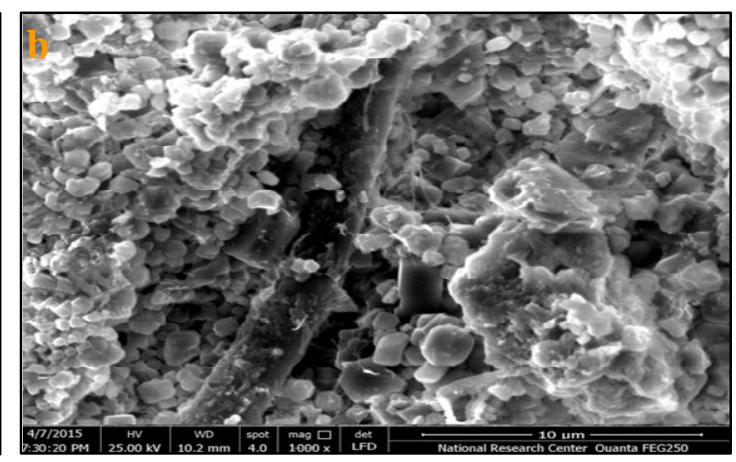



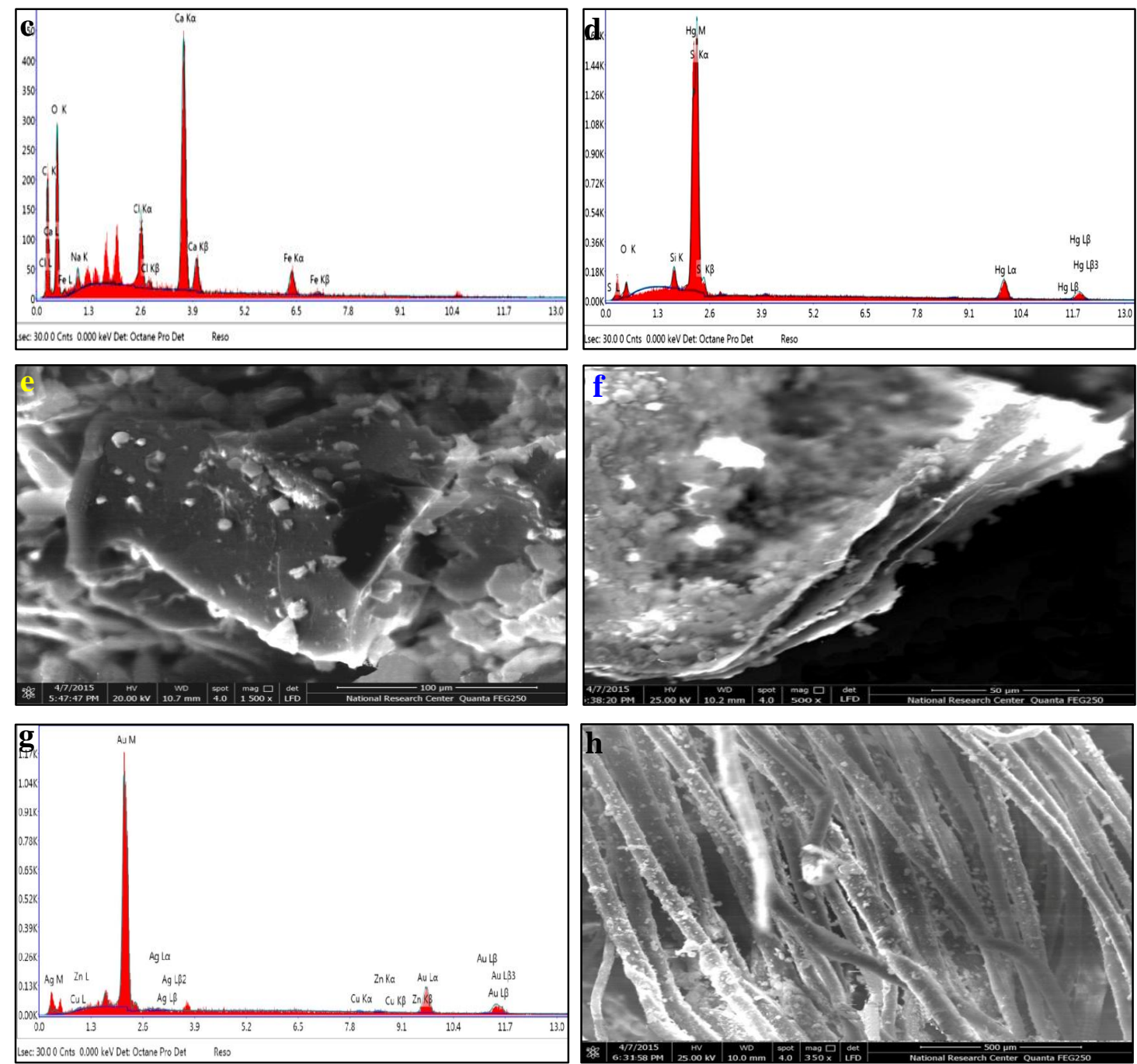

Figure (5) Shows a. SEM-BS micrograph of sample of the outer ground layer shows the gaps between the crystals, $\underline{\mathbf{b}}$. fungal hyphae overlapping between calcite granules, $\underline{\mathbf{c}}$. EDS spectrum of dark red layer, $\underline{\mathbf{d}}$. EDS spectrum of brilliant red layer, e. SEM micrograph of cuprorivaite crystal of blue paint layer, f. SEM micrograph of deterioration phenomena of gilding layer and separation of gold foils, g. EDS spectrum of gilding layer, $\underline{\mathbf{h}}$. SEM micrograph of textile support

\subsection{ATR-FTIR results}

The FTIR spectrum of the outer ground layer, fig. (6) revealed functional groups that indicate the presence of calcite only from preparation layer and no other functional groups showed any

organic medium. The characteristic bands of calcite showed at $1392 \mathrm{~cm}^{-1}$ which is attributed to $\mathrm{CO}^{32-}$ stretching (antisymmetric), peak at $871 \mathrm{~cm}^{-1}$ is due to O-C-O bending band (symmetric) [30,31].

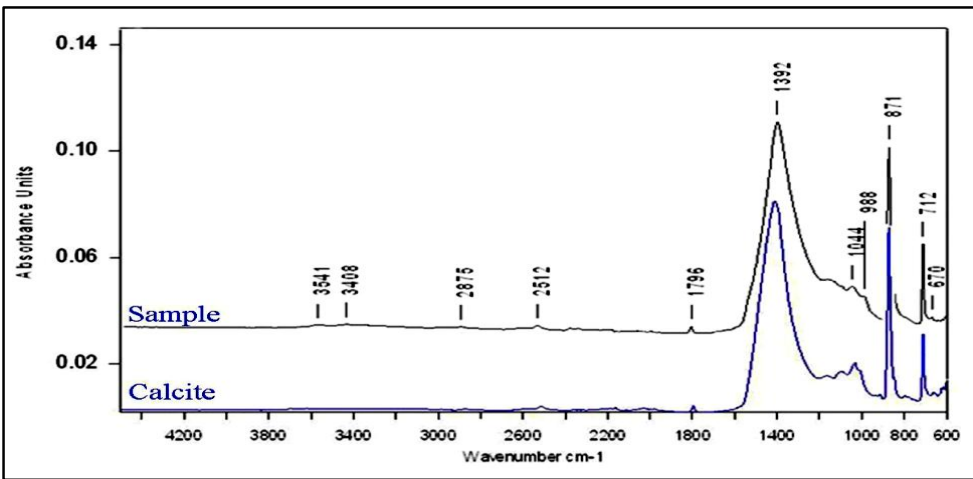

Figure (6) Shows ATR- FTIR analysis of the outer ground sample compared with reference sample 


\subsection{Microbiology damages:}

The microbiological examination of the cartonnage, fig. (7) showed that it infested with the following fungi: Aspergillus flavipes, Aspergillus ochraceus, Penicillium chrysogenum, Penicillium steckii and Scopulariopsis candida. Also found three bacterial species are Bacillus laterosporus, Bacillus coagulans, Micrococcus sp., and type one of Actinomycete is Streptomyces $s p$.
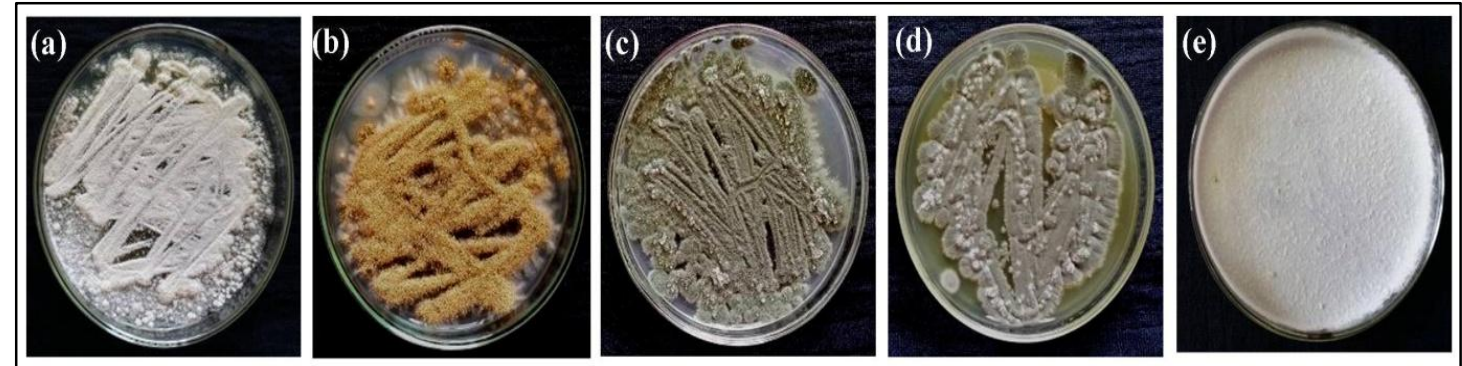

Figure (7) Shows different kind of fungi isolated from foot case cartonnage a. Aspergillus flavipes, $\underline{\mathbf{b}}$. Aspergillus ochraceus, $\underline{\mathbf{c}}$. Penicillium chrysogenum, $\underline{\mathbf{d}}$. Penicillium steckii, $\underline{\mathbf{e}}$. Scopulariopsis candida

\section{Discussion}

Optical Microscope, SEM and XRD results revealed that foot case cartonnage composed of five layers, the outer and inner ground layer. These layers are separated by two layers of tissue. The fourth and fifth layers are a layer of pigments and gilded. The SEM observation of the outer ground layer shows the weakness and lack of cohesion, this may be due to the natural aging process, where it is exposed to the organic medium used to connect the components of the ground layer. SEM of the inner ground layer shows presence of hyphae may be penetrated in the ground, degrading some of its components, which resulted in a decrease in the cohesion of the layers, thus giving rise to exfoliations and cracking [32]. Also the fungal hyphae are capable of etching and extending into the interior of the painted ground layer, resulting in enlargement of the damaged area and an increase in porosity [33]. The microscopic examination of the brilliant red layer shows some black spots in the brilliant red color that may be due to the beginning of the transformation of mercury sulfate $(\mathrm{HgS})$ to metacinnabar [34]. Furthermore, the crystal has appeared broken; this breakage is probably the beginning of the damage of the cinnabar and its transformation into metacinnabar. Cinnabar tends to darken to be form of the black metacinnabar $\alpha$ $\mathrm{HgS}$ [35]. The cause of cinnabar photosensitivity related to physical and chemical mechanisms such as photo-oxidation and changes in atomic structure [36]. SEMEDS of dark red and blue sample shows white crystals spread on the surface, while the results analysis showed that it contains of chloride $(\mathrm{Cl})$ and sodium (Na) and this indicates to the presence of halite $(\mathrm{NaCl})$ as a salt which is a common salt in the sandy burial environment $[37,38]$. SEM of gilded layer showed that there were three layers of gilding foil; they are separated from each other, possibly as a result of the loss of the organic medium used as an adhesive with natural aging. There is also erosion, fissures and protrusions in the gilded layers may be due to the application of more than one gilded layer or because of the shrinkage of the organic medium. FTIR-ATR results of the ground layer did not show any functional groups indicating the organic medium may be 
due to the spectrum of calcite has overlapping any other compound in the sample [39], or due to the natural aging of the binding media, which is noticed in the weakness of the ground layer. The microbiological examination of the cartonnage showed the presence of fungal and bacterial growth causing aesthetic damage due to colony formation and fungal pigments $[3,40]$, microorganisms exits the enzymes that are damaged organic binder and causes loss of paint layers [40].

\section{Conclusion}

The different analytical techniques have been used to study deterioration phenomena of foot case cartonnage. The results showed that it suffers from severe degradation as a result of discovery, then the return of his burial and it presence for a long time without the necessary treatment and conservation. The deterioration phenomena observed are fragile and distorted of cartonnage and weak, cracks and detachment of ground layer, flaking and exfoliation of paint layers, tears, excisions and holes of textile, erosion, fissures, protrusions of the gilding layers and. The microbiological examination showed the cartonnage was infected with a number of microorganisms. Optical microscope and SEM of brilliant red layer revealed black spot and breaks of crystals may be it is the beginning of the damage of the cinnabar.

\section{Acknowledgements}

I would like to express my thanks to Mr. Ashraf Fahmi and Amr Shakal at the ministry of state for antiquities affairs of Egypt (Saqqara site) for their helpful collaboration.

\section{References}

[1] Leach B. \& Tait J., (2000). Papyrus, in: Nicholson, P. \& Shaw, I. (eds.) Ancient Egyptian materials and technology, Cambridge Univ. Press, London, pp: 230-253.

[2] Rowe, S., Siddall, R. and Stacey, R., (2010) Roman Egyptian gilded cartonnage: Technical study and conservation of a mummy mask from Hawara, in: Dawson, J., Rozeik, C. \& Wright, M. (eds.) Decorated surfaces on ancient Egyptian objects: technology, deterioration and conservation, Archetype Pub., London, pp.106-121

[3] Afifi, H., (2012). Comparative efficacy of some plant extracts against fungal deterioration of stucco ornaments in the mihrab of Mostafa Pasha Ribate, Cairo, Egypt, American J. of Biochemistry and Molecular Biology, Vol. 2 (1), pp: 40-47.

[4] Shaw, I., (2003). Exploring ancient Egypt, Oxford Univ. Press, USA.

[5] Abdelrahim, S., (2009). Study of weathering forms at step pyramid limestone and its treatment, Saqqara, Egypt, in: Ferrari, A. (ed) $4^{\text {th }}$ Int. Cong. on Science and Technology for the Safeguard of Cultural Heritage in the Mediterranean Basin, Vol. II, Cairo, Egypt, pp: 401- 407.

[6] Magi, G., (2005). Saqqara. Ediz. Inglese, Casa Editrice Bonechi, Italy

[7] Bunson, M., (1995). Dictionary of ancient Egypt, Oxford Univ. Press, NY.

[8] Aufderheide, A., (2003). The scientific study of mummies, Cambridge Univ. Press, London.

[9] Chapman, J., (1997). Storing and handling plaster objects, National Park Service, Conserve O Gram, No 8/2, pp: 1-7

[10] Shelley, M., (1987) The care and handling of art objects, The Metropolitan Museum of Art, New York.

[11] Subbaraman, S., (1993). Conservation of mural paintings, Current Science, Vol. 64, pp: 736-753.

[12] Sakr, A., Ghaly, M., Ali, M. \& AbdelHaliem, M., (2013). Biodeterioration of binding media in tempera paintings by streptomyces isolated from some ancient Egyptian paintings, African Journal of Biotechnology, Vol. 12, pp: 1644-1656.

[13] Thomson, G., (1986). The museum environment, $2^{\text {nd }}$ ed., Butterworth, London. 
[14] He, X., Xu, M., Zhang, H., Zhang, B. \& Su, B., (2014). An exploratory study of the deterioration mechanism of ancient wall paintings based on thermal and moisture expansion property analysis, J. of Archaeological Science, Vol. 42, pp: 194-200.

[15] Rapp, G., (2009). Archaeominera$\log y, 2^{\text {nd }}$ ed., Springer, Germany.

[16] Günsicke, S., (2010). The conservation of decorated organic Egyptian surfaces: A literature review, in: Dawson, J., Rozeik, C. \& Wright, M. (eds.). Decorated surfaces on ancient Egyptian objects: Technology, deterioration and conservation, Archetype Pub., London, pp: 67-77.

[17] Moreno, E., Navas, N., Checa-Moreno, R., Rodriguez-Simón, L. \& CapitánVallvey, L., (2009). Preliminary study of UV ageing process of proteinaceous paint binder by FT-IR and principal component analysis, Talanta, Vol. 77, pp: 1724-1731.

[18] Gilroy, D. \& Godfrey, I., (1998). A practical guide to the conservation and care of collections, Western Australian Museum, Perth.

[19] Dennis, R., (1992). Pest control in museum, in: Thompson, J., Bassett, D., Duggan, A. \& Lewis, G. (eds.) Manual of curator ship: A guide to museum practice, Butterworth-Heinemann, Oxford, pp: 474-479.

[20] UNI EN 16085 (2012) (English): Conservation of cultural property methodology for sampling from materials of cultural property-general rules. The European Committee for Standarization, https://infostore.saiglobal. com/preview/is/en/2012/i.s.en160852012.pdf?sku=1566977, (5/10/2014.)

[21] Deacon, J., (1984). Introduction of modern mycology, Black Well Scientific Pub., Oxford.

[22] Rajain, S., (2000). Practical manual of fungi, ANMOL Pub., New Delhi.

[23] Dugan, F., (2006). The identification of fungi: An illustrated introduction with keys, glossary, and guide to literature, American Phytopathological Society, USA.
[24] Kird, P., Cannon, P., David, J. \& Stalpers, J., (2008). Dictionary of the fungi, CABI Publishing, UK.

[25] Bergery, D. \& Holt. J., (1989). Bergey's manual of systematic bacteriology, Vol. 2, Williams \& Wilkins, London.

[26] Cowan, S., Barrow, G., Steel, K. \& Feltham, R., (2003). Cowan and steel's manual for the identification of medical bacteria, Cambridge Univ. Press, London.

[27] Afifi, H., (2011). Analytical investigation of pigments, ground layer and media of cartonnage fragments from Greek Roman period, MAA, Vol. 11, No. 2, pp: 91-98.

[28] David, A., (2000). Mummification, in: Nicholson, P. \& Shaw, I. (eds.) Ancient Egyptian materials and technology, Cambridge Univ. Press, London, pp: 372-389

[29] Abd El-Tawab, N., Badr, I. \& Mahran, A., (2012). Analytical investigation of cartonnage fragment from late period, EJARS, Vol. 2 (2), pp: 69-78.

[30] lluveras, A., Boularand, S., Roqué, j., Cotte, M., girảldez, P. \& Vendrellsaz, M., (2008). Weathering of gilding decorations investigated by SR: Development and distribution of calcium oxalates in the case of Sant Benet de Bages (Barcelona, Spain), Applied Physical A, Vol. 90, pp: 23-33.

[31] Vetter W. \& Schreiner M., (2010). Characterization of pigment binding media systems comparison of non invasive in situ reflection FTIR with transmission FTIR microscopy, in: Maier, M. (ed.) $9^{\text {th }}$ Int. Conf. of the Infrared and Raman Users. Group (IRUG), Buenos Aires, pp: 10-22.

[32] Moussa, A., Mansour, M. \& Ayed, N., (2012). Study the role played by fungal growth in the deterioration of lime mortar: An example from Tunisia, EJARS, Vol. 2 (1), pp: 39-44.

[33] Afifi, H., Geweely, N., Galal, H., Abdelrahim, S. \& Al-Qudsi, F., (2016). Antimicrobial activity of gold nanoparticles (AuNPs) on deterioration of archeological gilded painted carton- 
nage, late period, Saqqara, Egypt, Geomicrobiology, Vol. 33 (7), pp: 578585.

[34] Brill, T., (1980). Light: Its interaction with art and antiquities, Plenum Press, NY.

[35] Saunders, D. \& Kirby, L., (2004). The effect of relative humidity on artists' pigments, National Gallery Technical Bulletin, Vol. 25, 62-72.

[36] McCormack, J., (2000). The darkening of cinnabar in sunlight, Mineralium Deposita, Vol. 35 (8), pp: 796798.

[37] Sakr, A., Ghaly, M. \& Ali, M., (2013). The relationship between salts and growth of streptomyces colonies isolated from mural paintings in ancient Egyptian tombs, Conservation
Science in Cultural Heritage, Vol. 13, pp: 313-330.

[38] Abd El Aal, Sh., (2014). Characterization and examination of pigments, grounds and media from ancient Egyptian cartonnage, EJARS, Vol. 4 (1), pp. 35-46.

[39] Abo El-Yamin, A., Mahmoud, H and Brania, A., (2013). Analytical study of Coptic wall paintings in Egypt, El-Bagawat necropolis, Kharga Oasis: A case study, Periodico di Mineralogia, Vol. 82 (1), pp: 25-40.

[40] Sterflinger, K., (2010). Fungi: Their role in deterioration of cultural heritage, J. of Fungal Biology Reviews, Vol. 24 (1), pp. 47-55. 